\title{
Joachim Minnemann (geb. 1949)
}

KASPAR (1976)

Joachim Minnemanns Gedicht erschien 1976 in der Anthologie Wir kommen. Literatur aus der Studentenbewegung. Die Anthologie ging aus einem Literaturwettbewerb der »Roten Blätter", Organ des Marxistischen Studentenbundes Spartakus, und des "Kürbiskern « hervor, als die Studentenbewegung bereits in Auflösung begriffen war. Minnemann artikuliert ein wichtiges utopisches Moment der Studentenbewegung: in impliziter Absage an Handkes "Ich möcht ein solcher werden wie einmal ein andrer gewesen ist " postuliert er die vollkommene Individualität, die in der Liebe, der Einmaligkeit der Partner füreinander herstellbar sei und den sneuen Menschen realisieren sollte.

\section{Kaspar}

(Für Elisabeth)

\author{
nimm mein wort \\ wiege es in deinen armen \\ sing dein lied \\ und ich bin ein solcher \\ wie nie ein anderer \\ gewesen ist
}

